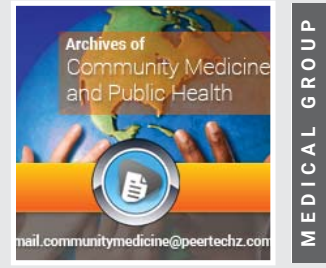

\title{
Why we should universally cover our mouth and nose in public while battling COVID-19?
}

\author{
Sary Beidas* \\ 8630 Midnight Pass Rd, Sarasota, FL, 34242, USA
}

Received: 23 April, 2020
Accepted: 27 April, 2020
Published: 28 April, 2020

*Corresponding author: Sary Beidas, MD, MBI, FACP, 8630 Midnight Pass Rd, Sarasota, FL, 34242, USA, E-mail:cmio.beidas@gmail.com

https://www.peertechz.com

Check for updates
Most of us are faithfully practicing the 6-foot social distancing rule in public. Some, are even wearing masks while driving alone. On April 3, 2020, the CDC issued voluntary guidelines for the use of cloth face mask (such as a scarf, bandanna or homemade mask) while in public spaces $[1,2]$. In support of CDC's recommendations for decreasing the transmission rate of COVID-19, we should all strive to wear a cloth face mask (or a standard surgical face mask) when in public when distancing is not feasible. For example, going to the grocery store. Why am I proposing to extend the CDC's voluntary guideline for using a face mask for anyone out in a public space is the subject of this opinion piece?

Physicians know that SARS-CoV-2, the virus responsible for COVID-19, is transmitted primarily by droplet (such as when sneezing or coughing) or touching an object laced by viral particles such as a door handle. What we don't know is the extent of SARS-CoV-2 transmission by aerosol. Aerosols mean that infectious virus is suspended in air for longer periods of time facilitating viral transmission by the simple act of breathing or talking.

Evidence suggests that the aerosol route may indeed play a role in transmission of SARS-CoV-2 [3,4]. And if aerosol transmission does occur, wearing a face mask (standard surgical or cloth) may minimize the droplet or aerosol an individual generates while breathing, coughing or sneezing. But what about individuals who don't want to use facial mask protection when in public spaces?

Not wearing a mask, regardless of mask type, increases the likelihood of viral transmission. Another perspective on voluntary wear of masks, in particular, cloth masks, suggests that wearing a cloth face mask may paradoxically increase the likelihood of facilitating the transmission of virus [5]. For example, an individual wearing a cloth mask, limits droplet or aerosol generation. On the other hand, it does not limit an individual who is not wearing a mask from generating viral particles in droplets or aerosol. Hence, if mask wearing is not universally practiced in public, breaking the cycle of COVID-19 transmission may not be as effective.

Other ostensible reasons for this increase in transmissibility of virus may include humidity, fabric type, fabric characteristics, electric charge of the fabric and the individual's hygiene [6]. For example, humidity during exhaling accumulates in the cloth around the mouth and nose which may attract viral particles on the cloth cover thus increasing the opportunity for mucosal surfaces to come in contact with the virus. The longer one keeps on a face cloth cover, the more humidity accumulates on the cloth. Ideally, a facial cloth cover should be used for the least time possible to minimize humidity. Thereafter, the mask should be washed and completely dry before reuse. For practical reasons, it makes sense to have several facial masks handy and use a clean mask when you need to wear one.

Therefore, to counter the paradox of potential increased transmissibility of SARS-CoV-2 while using cloth facial covers it makes sense to extend CDC's voluntary use of cloth face masks for everyone planning to be in a public space until we have a vaccine or acceptable therapy for SARS-CoV-2. 


\section{References}

1. Use of Cloth Face Coverings to Help Slow the Spread of COVID-19. Link: https://bit.ly/2W54ico

2. CDC (2019) Recommendation Regarding the Use of Cloth Face Coverings, Especially in Areas of Significant Community-Based Transmission. Link: https://bit.ly/3bCrwgC

3. Santarpia J, Rivera D, Herrera V, Morwitzer J, Creager H, et al. (2020) Transmission Potential of SARS-CoV-2 in Viral Shedding Observed at the University of Nebraska Medical Center. medRxiv. Link: https://bit.ly/359T6Q7
4. National Research Council 2020 (2020) Rapid Expert Consultation on the Possibility of Bioaerosol Spread of SARS-CoV-2 for the COVID-19 Pandemic. Link: https://bit.ly/3blyZuB

5. Washington, DC: The National Academies Press. Link: https://bit.ly/2Kz35F5

6. Maclntyre CR, Seale H, Dung TC, Hien TN, Nga PT, et al. (2015) A cluster randomised trial of cloth masks compared with medical masks in healthcare workers. BMJ Open 5: e006577. Link: https://bit.ly/2zyQr6I

7. Neupane B, Mainali S, Sharma A, Giri B (2019) Optical microscopic study of surface morphology and filtering efficiency of face masks. PeerJ 7: e7142. Link: https://bit.ly/2S5lvkX

\section{Discover a bigger Impact and Visibility of your article publication with}

Peertechz Publications

\section{Highlights}

* Signatory publisher of ORCID

* Signatory Publisher of DORA (San Francisco Declaration on Research Assessment)

* Articles archived in worlds' renowned service providers such as Portico, CNKI, AGRIS, TDNet, Base (Bielefeld University Library), CrossRef, Scilit, J-Gate etc.

* Journals indexed in ICMJE, SHERPA/ROMEO, Google Scholar etc.

* OAI-PMH (Open Archives Initiative Protocol for Metadata Harvesting)

* Dedicated Editorial Board for every journal

* Accurate and rapid peer-review process

* Increased citations of published articles through promotions

* Reduced timeline for article publication

Submit your articles and experience a new surge in publication services (https://www.peertechz.com/submission).

Peertechz journals wishes everlasting success in your every endeavours.

Copyright: (c) 2020 Beidas S. This is an open-access article distributed under the terms of the Creative Commons Attribution License, which permits unrestricted use, distribution, and reproduction in any medium, provided the original author and source are credited. 